\title{
The Law of Nuisance in Canada, Gregory S Pun \& Margaret I hall (MARKHAM, ONT: LEXISNEXIS, 2010)
}

“There is perhaps no more impenetrable jungle in the entire law,” Dean Page Keeton once wrote, "than that which surrounds the word "nuisance.", ${ }^{1}$ Such impenetrability may explain steps taken in England to subsume nuisance law into the fault-based law of negligence. ${ }^{2}$ It does not take much imagination to appreciate why the English would move in that direction. At some point, after all — Dean Keeton's jungle floor having become impossible to navigate - practitioners and judges must be tempted to join the academic lawyers who gaze down from the treetops. The perspective from the canopy might well persuade them that their problem is not amenable to the small doctrinal fix of cutting a path through a grove or two. Rather, it is more fundamental, going to the very lay of the land. They therefore abandon nuisance law's tangled thickets altogether, preferring — to bring the metaphor home now for a decent burial — the broader and more familiar paths of negligence law.

Who can blame them? Certainly not the academic lawyers, most of whom (the reviewer included) have had nothing new to say about nuisance law in decades. And yet, it is a joy for us to teach. Following the casebook I use in my first-year torts class, ${ }^{3}$ I dedicate the first three weeks of the course to teaching private nuisance. There are practical reasons for this: the subject matter intrigues students (particularly its environmental bent), and it offers several opportunities for demonstrating the common legal process of refining legal rules over time. More fundamentally, however, early examination of the tort of nuisance instills in students from the outset of their legal studies the idea that the mere occurrence of harm does not, without an injury to a right, generate a cause of action. ${ }^{4}$ It also emphasizes for students that, while questions going to liability are obviously important, so is the question of remedy. And, it is in the course of distinguishing between the remedial options of an injunction and damages that students are also introduced to the venerable judicial struggle, common to the rest of tort law but neatly instantiated in nuisance claims, between the orthodox conception of tort law as a device for vindicating injured rights, and the allure of using tort law as a tool for advancing "public policy" imperatives. In the specific instance of nuisance law, the choices are stark, and the answers (from the standpoint of an earnest first-year student) not easy. Will or should, for example, the court throw hundreds of factory hands out of work in order to ease the laboured breathing of the next-door neighbour? Or, can the breadwinners continue to sustain their families, subject to the factory paying the neighbour damages essentially a licence fee which, once paid, entitles it to ruin her health? This is an old dilemma, and becomes even more vexing when applied not to the question of remedy, but to the prior question of whether a nuisance should be found at all. I will return to this subject towards the conclusion of this review.

The tort of nuisance also remains a useful lawyer's tool, and it is to that audience that Gregory Pun and Margaret Hall's new co-written textbook, The Law of Nuisance in Canada, ${ }^{5}$

W Page Keeton, ed, Prosser and Keeton on the Law of Torts, 5th ed (St Paul, Minn: West Publishing, 1984) at 616.

See Overseas Tankship (UK) Ltd v Miller Steamship Co Pty (1966), [1967] 1 AC 617 at 639: “although negligence may not be necessary, fault of some kind is almost always necessary."

Ernest J Weinrib, Tort Law, 3d ed (Toronto: Emond Montgomery, 2009).

Fontainebleau Hotel Corp v Forty-Five Twenty-Five Inc, 114 So (2d) 357 (Fla App 1959).

Gregory S Pun \& Margaret I Hall, The Law of Nuisance in Canada (Markham, Ont: LexisNexis, 2010). 
is directed. The first comprehensive work on Canadian nuisance law in 20 years, ${ }^{6}$ the authors have produced a useful encapsulation and organization of the Canadian jurisprudence. The standard subject matter of nuisance - including questions of local standards, sensitive plaintiffs, standing, and remedy — are covered ably and, so far as Canadian case authorities are concerned, exhaustively. Perhaps the greater contribution, however, lies in the careful attention to aspects of nuisance law which, being a little off the beaten track, have received little or no recent attention from lawyers, practicing or academic. For example, the section on "Public Nuisance," written by Mr. Pun, comments on the distinction — the logic of which, I confess, eludes me still - between private nuisance and the rule that allows an individual to sue where they are the victim of "special damage" because of interference resulting from a public nuisance. ${ }^{7}$ This is distinct from the aspect of public nuisance that deals with injury to a public right — that is, an interest which all persons share in common — such as the right to use public roadways, sidewalks, and parks. Rather, the injury here constitutes widespread damage to or interference with multiple occupiers' use and enjoyment of their lands. Pun says (and this makes sense) that such cases are best understood not as truly public nuisances, but as widespread private nuisances and ought to be treated accordingly. ${ }^{8}$

The most interesting and provocative element of the book - and, given the book's predominant focus upon case authorities, what might eventually prove its most enduring contribution - is Professor Hall's section on the Rule in Rylands v Fletcher. ${ }^{9}$ The Rule, from its origins, has been shrouded in ambiguity, owing to two distinct formulations that emerged from Rylands $v$ Fletcher: one which emphasizes non-natural use of land, combined with an escape; and another which connotes inherent dangerousness by emphasizing that the escape would lead to mischief. Sometimes the rule is taught as two different versions. Alternatively, it is taught as a unified version — that non-natural use and inherent dangerousness are simply different aspects of a common idea — but the idea itself is never clearly identified. The case authorities either fail to recognize the ambiguity or fail to clarify which understanding of the rule is being applied. Frustratingly, a comprehensive review of the case law discloses no clear trend. No wonder the Australians have abandoned the Rule altogether. ${ }^{10}$

Many academic lawyers would respond to this mess by imposing a theoretical, normative structure and then sorting the cases that fit from those that do not, and discarding the latter as wrongly decided. The strength of Hall's solution is that she constructs a taxonomy from the cases themselves. Mindful that, as a species of strict liability, the Rule is most coherently viewed as imposing liability on the basis of risk-creation, she conceives - carefully drawing from the case authorities — of the Rule as requiring the plaintiff to show that the defendant

The previous work was Beth Bilson, The Canadian Law of Nuisance (Toronto: Butterworths, 1991). Pun echoes the lament (supra note 5 at 34) of the Nova Scotia Court of Appeal in Vaughn v HalifaxDartmouth Bridge Commission (1961), 29 DLR (2d) 523 at 524, that the law "fails to reveal, at least to me, a distinction that is entirely satisfactory."

Pun \& Hall, ibid at 51.

Rylands v Fletcher (1868), 3 LRHL 330. Strictly speaking, of course, the Rule in Rylands $v$ Fletcher is not a part of nuisance law, since the gist of the action is not an interference with use and enjoyment of land. Indeed, the plaintiff need not even own land. The Rule, however, is often combined in the literature with nuisance. See e.g. Bilson, supra note 6. Claims in nuisance and under the Rule in Rylands $v$ Fletcher are also often combined: for a recent example (which cites the text being reviewed here), see Smith v Inco Ltd, 2011 ONCA 628, [2011] OJ no 4386 (QL). 
actively participated in that risk-creation. Alternating emphases in the case authorities for (non-)naturalness and for dangerousness are thereby reconciled as instances where different factors that might inform the analysis regarding the quality of the risk are examined. There is no need for courts to choose one over the other, because they have both been considered relevant dimensions of risk-creating behaviour at different times.

My sole quibble with this otherwise excellent book - the best current resource on the Canadian law of nuisance - requires some background explanation. Ironically, the root of the problem lies in the book's superb introduction, which includes a scholarly contribution from Christopher Harvey, on the history of the tort of nuisance. ${ }^{11}$ Harvey describes a line of cases - which is still taught in Canadian law schools — going back to Aldred's Case, ${ }^{12}$ and carrying on through to Baron Bramwell's speech in Bamford v Turnley. ${ }^{13}$ These cases reject the argument that the determination of whether the defendant has committed a nuisance can in any way be determined with reference to the public benefit secured by the defendant's activity. In Bamford $v$ Turnley, for example, the defendant's brick-making operation, which entailed burning bricks in a kiln thereby generating noxious fumes that spread to the surrounding area and rendered the plaintiff's household ill, was said by the defendant to be socially beneficial and, as such, should not be impugned as a nuisance. In a classic statement of Kaldor-Hicks efficiency, Baron Bramwell rejected the sacrificing of private rights on the altar of public benefit:

\footnotetext{
The public consists of all the individuals of it, and a thing is only for the public benefit when it is productive of good to those individuals on the balance of loss and gain to all. So that if all the loss and all the gain were borne and received by one individual, he on the whole would be a gainer. But whenever this is the case, whenever a thing is for the public benefit, properly understood, — the loss to the individuals of the public who lose will bear compensation out of the gains of those who gain. It is for the public benefit there should be railways, but it would not be unless the gain of having the railway was sufficient to compensate the loss occasioned by the use of the land required for its site; and accordingly no one thinks it would be right to take an individual's land without compensation to make a railway. It is for the public benefit that trains should run, but not unless they pay their [expenses]. ${ }^{14}$
}

Something is only a truly public benefit, then, where no individual goes uncompensated for any violation of his or her rights. One cannot simply infringe others' rights, even for a public benefit, to those others’ prejudice. “This,” says Harvey, "should have ended the heresy of public benefit for all time." ${ }^{\prime 5}$ And yet, as he correctly describes, "reformist” judges such as Lord Denning have invoked “public benefit” to justify all manner of outrages against the rights of neighbours to use and enjoy their property. ${ }^{16}$

This is a fundamental concern that arises from even the most elementary study of the tort of nuisance. Much of the in-class discussion between tort law instructors and their students respecting nuisance (and, indeed, respecting much of tort law) goes to the judicial bargaining

Pun \& Hall, supra note 5 at 18-32.

William Aldred's Case (1610), 9 Coke Rep 57b.

(1860), 122 ER 27.

Ibid at 33.

Pun \& Hall, supra note 5 at 31.

Ibid at 32. The most notorious example, at least among Lord Denning's decisions, is Miller v Jackson, [1977] QB 966. 
between the orthodoxy of private rights and what Harvey describes as the "heresy" of public benefit. And yet, it is not clear where the authors stand on this divide. The opportunity for commentary arises at many critical junctures within the text, particularly in the chapter on private nuisance. ${ }^{17}$ In the course of discussing the reasonableness of the impugned damage or interference, for example, "the utility of the defendant's conduct" is identified as a factor that arises in the cases. ${ }^{18}$ Surprisingly, given Harvey's statement, not a word of normative objection is raised to this consideration. Surely, if Harvey's statement is correct - and there is good reason for supposing that it is - what should matter is the materiality of the plaintiff's injury, and not the social gain to be derived from the defendant's conduct. Yet, having been provoked into considering this question by Harvey's statement, we are then left to draw our own conclusions, even where the cases under discussion take us precisely where he says they should not.

While the reader is occasionally left wanting more by way of engagement with the old debate between vindicating private rights and preserving public benefits, this is nonetheless a thoroughly researched and comprehensive account of the Canadian law of nuisance and of the Rule in Rylands $v$ Fletcher. Its taxonomy of the Rule in Rylands $v$ Fletcher is creative and potentially groundbreaking.

\author{
Russell Brown \\ Associate Professor and \\ Associate Dean (Graduate Studies) \\ Faculty of Law \\ University of Alberta
} example in Pun \& Hall, ibid at 42, of "the utility of the defendant's conduct" as a factor going to the unreasonableness of the interference in cases of public nuisance. 